\title{
The Occurrence of Silver-Gold Mineralization Associated With Uranium Bearing Minerals and Base Metal Sulphide, El Sheikh Soliman Area, South Sinai, Egypt.
}

\author{
Osama R. Sallam, Abdalla S. Alshami, Mohamed S. Azab and Ismail A. El Akeed \\ Nuclear Materials Authority, P.O. Box - 530 Maadi, Cairo, Egypt
}

\section{A R T I C L E I N F O}

Article history:

Received 31 August 2014

Accepted 24 September 2014

Keywords:

Hydrothermal solution;

Younger granites;

Shear zone;

Um Bogma formation.

\begin{abstract}
A B S T R A C T
El Sheikh Soliman area in southwestern Sinai is covered by Late Proterozoic monzo- and syenogranites, Paleozoic-Mesozoic sedimentary rocks. In the present study, first recorded important minerals bearing $\mathrm{Ag}$ and $\mathrm{Au}$ namely uytenbogaardtite and furutobeite are recorded in the lower member of Um Bogma Formation and laforetite (Ag-bearing) in monzogranites and syenogranites shear zone. Ag-Au mineralization in the lower member of Um Bogma Formation is associated with mineral assemblage hosting uranium and some others base metals namely; xenotime, yttrobetafite- $\mathrm{Y}$, cochromite, wakefieldite-( $\mathrm{Y})$ and bafertisite. The mineral assemblage in the monzo- and syenogranite shear zone includes; clinobehoite and xenotime. The mineralized zones in this area in part have features of hydrothermal origin in both the monzo- and syenogranites shear zone and in Um Bogma Formation, while, in the other member of Um Bogma Formation they are sedimentary as weathering products of the earlier assemblage detrital paleoplacer deposits.
\end{abstract}

\section{Introduction}

Sinai Peninsula is a famous polymetallogenetic province in Egypt, such as ferromanganese, copper, and uranium with other rare metals which in part have close relationship with Paleozoic sedimentary and surrounding granitic rocks. The Paleozoic sedimentary rock units in south Sinai exist unconformable on the extreme northern boundary of granitic Proterozoic terrains rocks.

El Sheikh Soliman area is bounded by long. $33^{\circ} 19^{\prime} 12^{\prime \prime}$

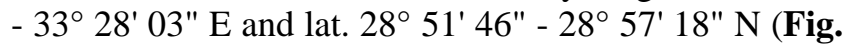
1). Younger granites in El Sheikh Soliman area undergo varying degrees of alteration, especially along fracture planes where acts as pathways for hydrothermal solutions. Changes in geochemical, mineralogical and textural characteristic of the wall rocks along shear zones attract attention of many authors ${ }^{[1-7]}$. These alterations were an explorations guide to mineral deposits and its hydrothermal origin.

In the study area, the younger granites in part are nonconformably overlain by the Paleozoic succession that capped by Triassic basalt sheet.

The Paleozoic sedimentary rock units in the study area comprise three stratigraphic units arranged from base to top: Lower Sandstone Series, Um Bogma Formation and

\footnotetext{
* Corresponding author.

E-mail address: orsallam@yahoo.com
}

the Upper Sandstone Series. The Lower Sandstone Series of Barron ${ }^{[8]}$, classified into Sarabit El Khadim, Abu Hamata and Adedia formations by Soliman and Abu El Fetouh ${ }^{[9]}$, the Middle Carbonate Series of Barron ${ }^{[8]}$, renamed as Um Bogma Formation by Weissbrod ${ }^{[10]}$, the Upper Sandstone Series of Barron ${ }^{[8]}$, comprising ElHashash, Magharet El-Maiah and Abu Zarab formations by Soliman and Abu El Fetouh [9], and Upper Sandstone Series of Barron ${ }^{[8]}$, renamed as Abu Thora Formation by Weissbrod ${ }^{[11]}$.

Many authors studied such mineral deposits within the Paleozoic sedimentary rocks in Abu Zeneima area such as; Al, U-Th, $\mathrm{Cu}$ and $\mathrm{Zn}, \mathrm{El}$ Aassy et al., ${ }^{[12-14]}$, Mn and $\mathrm{Cu}$; Ag, Amer ${ }^{[15]}$, U, Mo, As, and V, Mahdy et al., ${ }^{[16]}$; Mn, El Agami et al., [17], El Agami ${ }^{[18]}$, Aita [19], and Ghonaim et al., ${ }^{[20,21]}$.

\section{Methodology}

Ten representative samples weighting from 4 to $5 \mathrm{~kg}$ for each of the mineralized rocks were collected to determine their mineralogical constituents. After the samples were crushing and screening the grain size 0.5 $\mathrm{mm}-0.074 \mathrm{~mm}$ were subjected to systematic ore mineral separation techniques using a heavy liquid bromoform of Sp.G.=2.85 as and magnet. The obtained heavy mineral fractions were subjected to the binocular microscope and 


\section{X-ray diffraction (XRD) investigation.}

The radiometric measurements of eU (ppm), eTh (ppm) and $\mathrm{K} \%$ of the studied rock units were obtained using a portable differential gamma ray spectrometer model GS512, serial No. 9805, manufactured by Czech Republic, when the readings were given directly each 30 second. All laboratory works were done in the Central Laboratories of the Nuclear Materials Authority (NMA), Cairo, Egypt.

\section{Geologic setting}

The exposed rocks in El Sheikh Soliman area are mainly of Late Proterozoic crystalline rocks which partly nonconformably covered by the Paleozoic sedimentary rocks (Fig. 1). The Paleozoic section in many parts is cut by the Triassic-Jurassic basalt dykes and sheet.

The crystalline rocks in the study area are represented mainly by younger granites. Younger granites are classified by El Aassy et al., ${ }^{[22]}$ as monzo- and syenogranites.

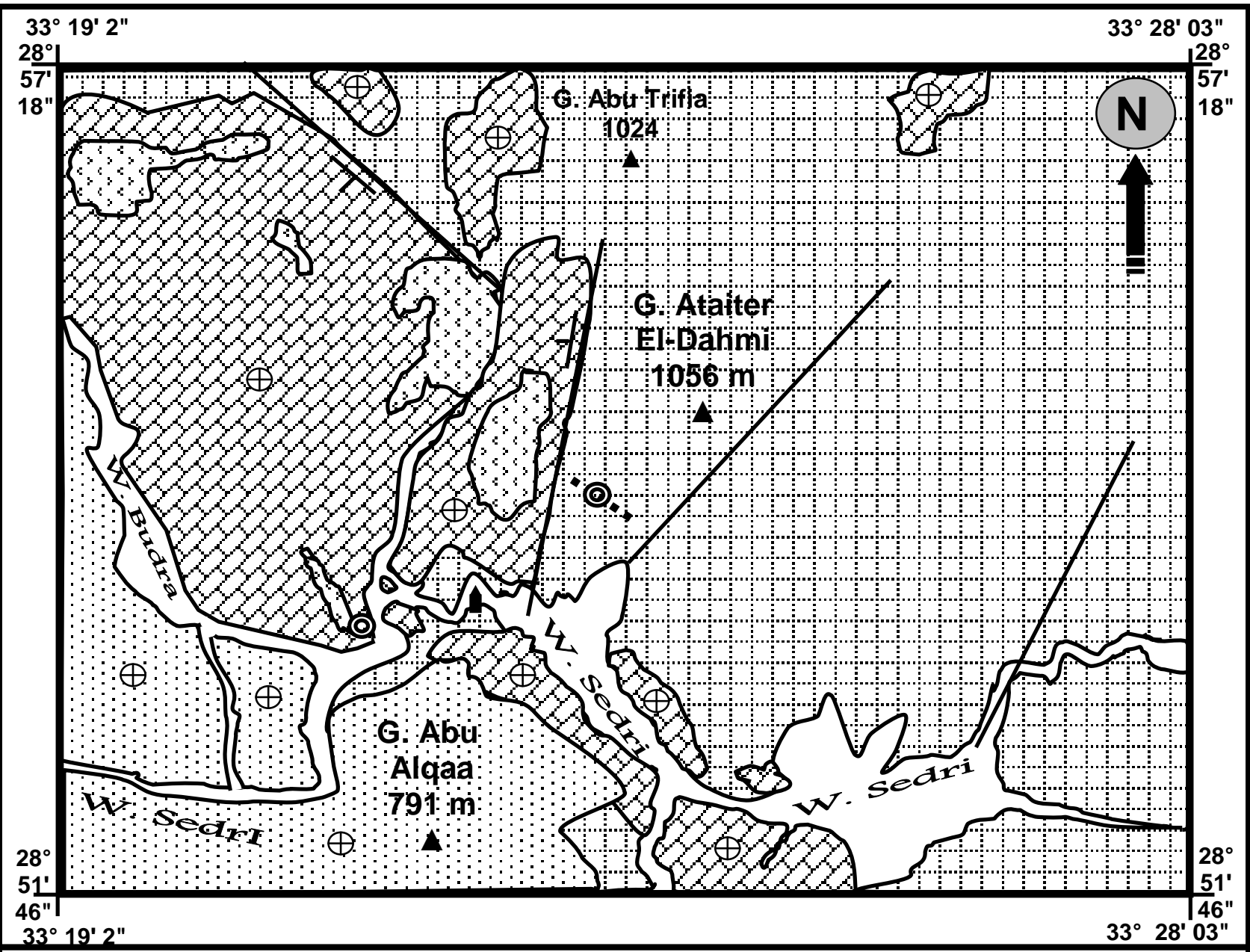

Fig. (1): Geologic map of El Sheikh Soliman area.

(Modified after El Akeed et al., ${ }^{[23]}$ )

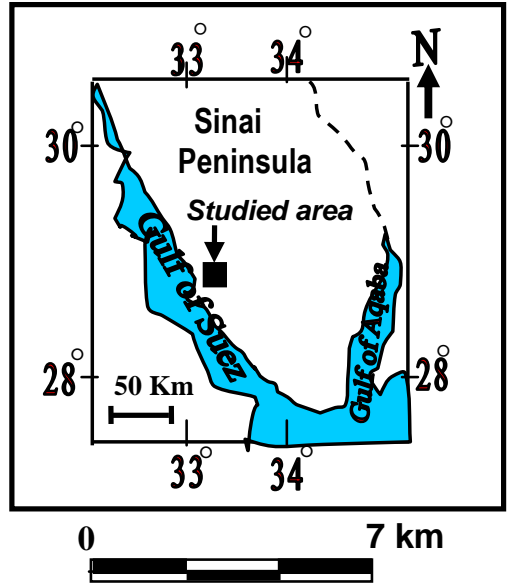

Post Paleozoic sedimentary rocks

Basalt sheet

Paleozoic sedimentary rocks

Monzo- and syenogranites

Y. Major normal fault

$\because$ Shear zone

$\oplus$ Horizontal layers

(2)

Location of the mineralized sample

Tomb of El Sheikh Soliman

$1056 \mathrm{~m}$ Triangulation points in meter 
The study younger granites are traversed by shear zone varies from 15 to $20 \mathrm{~m}$ in width, about $750 \mathrm{~m}$ extension and trending $\mathrm{N} 45^{\circ} \mathrm{W}-\mathrm{S} 45^{\circ} \mathrm{E}$ with nearly vertical dip ${ }^{[7]}($ Fig. 2A). The shear zone is dissected in some zones by pegmatite pockets (Fig. 2B) and quartz veins (Fig. 2C).

Ferrugination, silicification and kaolinitization with few dark patches of manganese (Fig. 2D) are the main alteration features developed within the studied shear zone. Shear zone is suitable for circulating hydrothermal solutions and act as favorable sites for mineralization. The alteration processes along the studied shear zone of Gabal Ataiter El-Dahmi area are mostly due to acidic hydrothermal activity changed to alkaline with time ${ }^{[7]}$.

In parts, Monzo- and syenogranites in the area are nonconformably covered by the Paleozoic sedimentary rock units (Fig. 2E). The Paleozoic succession in the area is as follows (started by the oldest); Sarabit El Khadim, Abu Hamata, Adedia, Um Bogma, El Hashash, Magharet El Maiah and Abu Zarab formations.

Um Bogma Formation in the study area is subdivided into three members as follows: Lower member comprising; siltstone, claystone, sandy dolostone, Fe-Mn ore, shale and ferruginous sandstone, middle member comprising; marl, dolostone and shale and upper member comprising sandy dolostone, shale and claystone.

Structurally, the studied area was affected by a number of major normal faults trending NW and NEN (Fig, 1\& 2F) with obvious alteration zone along fault zone extended deeper through middle and lower members of Um Bogma and Adedia formations.
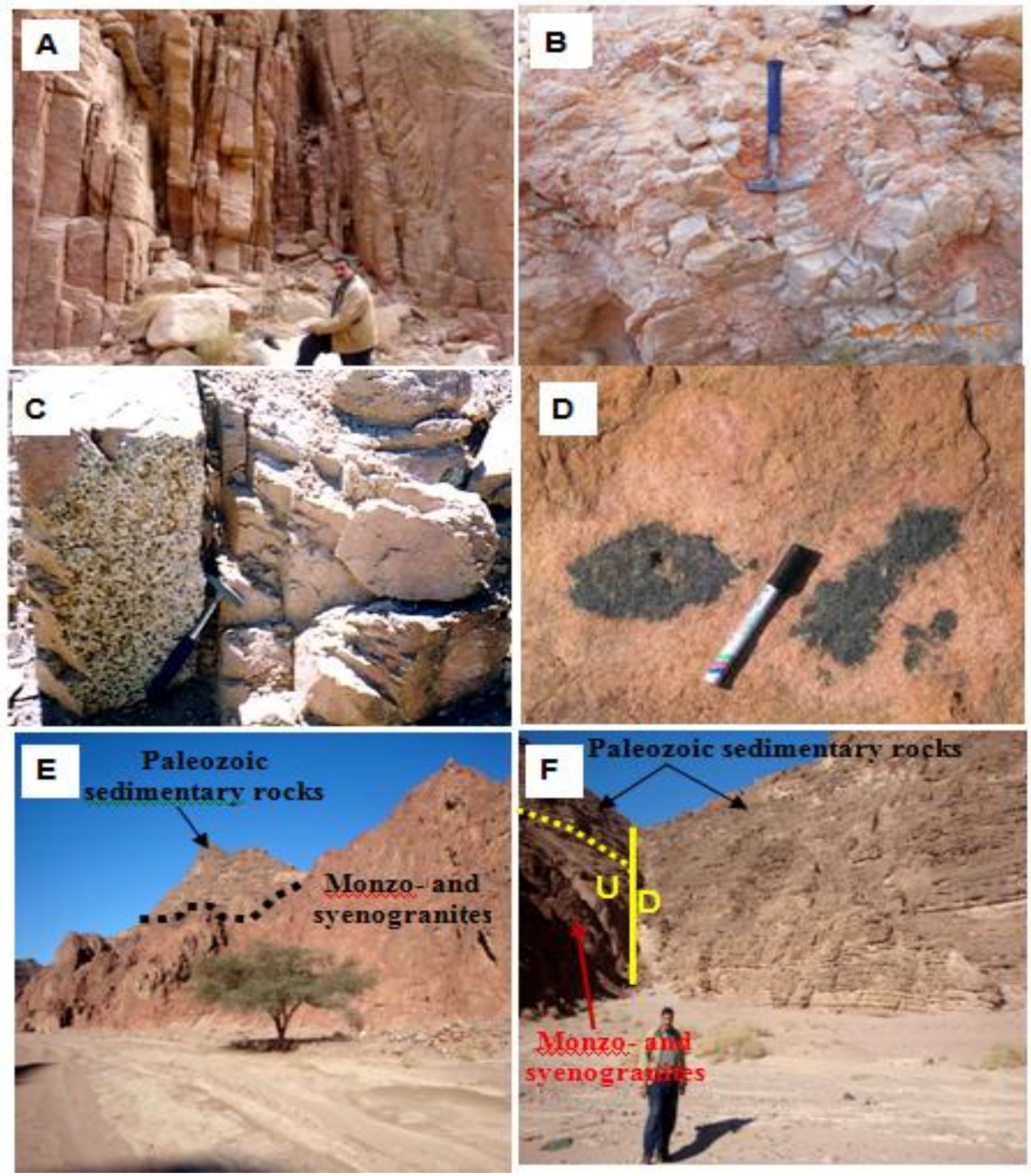

Fig. (2): A- Fractured younger granites along shear zone, looking SE. B- Pegmatite in sheared monzo- and syenogranites. C- Iron oxides and quartz veins occurred as fractures filling in the shear zone. D- Patches of manganese in sheared monzo- and syenogranites. E- Monzo- and syenogranites nonconformably covered by the Paleozoic sedimentary rocks, looking W. F- Normal fault affected in Monzo- and syenogranites and Paleozoic sedimentary rocks, looking NW. 
According to the radioactivity, some spots of altered monzo- and syenogranites shear zone measurements show high value of eTh content (ranges between 196.1 and $295.2 \mathrm{ppm}$ ) relative to the $\mathrm{eU}$ content (ranges between 28.7 and $47.5 \mathrm{ppm}$ ).

In the lower member of Um Bogma Formation is recorded very high value of eU content (ranges between 98.7 and $1356 \mathrm{ppm}$ ) relative to the eTh (ranges between 15.7 and $29.8 \mathrm{ppm}$ ).

\section{Mineralogical studies}

El Akeed et al. ${ }^{[23]}$ recorded in the sedimentary succession of Um Bogma and Adedia formations several important mineral assemblage association, such as: coffinite, marcasite, zincochromite, sodium metaautonite, and pucherite in addition to the $\mathrm{Fe}-\mathrm{Mn}$ predetected ore deposits. Good relation is noticed between these minerals and both the structural elements and lithology.

The mineralogical samples that collected from altered monzo- and syenogranites at the shear zone and from the lower member of Um Bogma Formation of El Sheikh Soliman area were studied to determine their content from important mineral varieties.

The obtained minerals include laforetite (Ag-bearing), clinobehoite and xenotime in the altered monzo- and syenogranites of the shear zone. While, includes; xenotime, confined locally identified $\mathrm{Au}-\mathrm{Ag}$ sulfides as furutobeite and uytenbogaardtite, yttrobetafite-Y, cochromite, wakefieldite-(Y) and bafertisite. In addition some accessory minerals, barite, malachite and iron oxides are recorded in the lower member Um Bogma Formation.

A- Mineralization of sheared monzo- and syenogranites:-

\section{1- Laforetite: $\mathbf{A g I n S}_{\mathbf{2}}$}

The XRD examination of the picked grains shows the association of Laforetite mineral with Clinobehoite and xenotime (Fig. 3).

\section{2- Clinobehoite: $\mathrm{Be}(\mathrm{OH})_{2}$}

Clinobehoite is identified by using the XRD technique (Fig. 3).

El-Aassay et al. ${ }^{[24]}$ mentioned the presence of beryl in pink feldspar pegmatitic veins in a granitic enclave within the sheared pink granite.

Abdalla and Mohamed [25] mentioned that beryl associates with granitoids in pegmatite veins, greissen bodies and cassiterite quartz veins.

In Wadi Sedri area, Sherif et al. ${ }^{[26]}$ recorded the presence of large independent beryl crystals associated with large quartz crystals in the post tectonic Be-bearing quartz veins indicating of probably formation in the later pegmatitic-pneumatolytic phases.

\section{3- Xenotime: $\mathrm{YPO}_{4}$}

Xenotime identified by using the XRD technique (Fig. 3).

B- Mineralization of Um Bogma Formation (lower member):-

\section{1- Xenotime:- $\mathrm{Y} \mathrm{PO}_{4}$}

Two forms of xenotime are detected in the study area within the siltstone of the lower member of Um Bogma Formation. The XRD examination of the picked grains shows the association of furutobeite mineral with xenotime (Fig. 4).

Xenotime small forms are anhedral to subrounded grains of dark brown color; reflecting effect of long distance transportation. Xenotime larger forms are prismatic euhedral to subhedral crystals with dark reddish brown color reflecting in situ and/or short distance transportation. It was transported from the widely distributed surrounding Precambrian younger granites and other basement rocks.

El-Kammar et al. ${ }^{[27]}$ stated that the high base-metals contents in Um Bogma Formation at Wadi El Sahu and Ramlet Hemiyir (north and northeast of the study area respectively) are confined to xenotime and to less extent to the ferromanganese mineral deposit. They reported that xenotime in Um Bogma Formation contains high content of HREEs and some base metals elements. Xenotime grows in sediments during diagenetic processes.

\section{2- Furutobeite:- $\left[(\mathbf{C u}, \mathbf{A g})_{6} \mathbf{P b S}_{4}\right]$}

Furutobeite is a copper, silver, lead sulfate mineral. It is detected in Um Bogma siltstone and shale by using XRD technique (Fig. 4). It occurs as anhedral to subhedral grains with no obvious forms and gray color with metallic luster. Represented by strongest three lines [d in $\AA$ (I) (hkl)] are 2.50 (100), 2.61(67.1), 2.14(8.9).

\section{3- Uytenbogaardtite :- [Ag Au $\mathrm{S}_{2}$ ]}

Uytenbogaardtite is detected within the siltstone of the lower member of Um Bogma Formation. It occurs as, pale grey color, small and irregularly shaped anhedral grains alone or in contact with furutobeite grains. The $\mathrm{X}$ ray diffraction data reveals association of uytenbogaardtite with yttrobetafite-Y minerals. Both are represented by the strongest three lines (A\&B) of the $\mathrm{X}$ ray powder-diffraction pattern $[d$ in $\AA(I)(h k l)]$ are: $2.712(100), 2.591(80), 1.980(34)$ at $2 \theta$ angles $33^{\circ}$, $34.6^{\circ}$ and $49.45^{\circ}$ respectively (Fig. 5).

Cook and Chryssoulf ${ }^{[28]}$ stated that, in some cases, gold is chemically combined within sulfide minerals rather than as discrete mineral inclusions. Gold and silver minerals deposition is related to remobilization by lowtemperature oxidizing groundwater and then redeposit in sulfide rich reducing environment. Supergene process leads to secondary enrichment of some metal deposits.

\section{4- Yttrobetafite-Y:- $\left[(\mathrm{Y}, \mathrm{U}, \mathrm{Ce})_{2}(\mathrm{Ti}, \mathrm{Nb}, \mathrm{Ta})_{2} \mathrm{O}_{6}(\mathrm{OH})\right]$}

Yttrobetafite-Y is identified using XRD (Fig. 5). It occurs as greenish to reddish color, dull luster, subhedral to anhedral crystals in the siltstone and variegated shale of Um Bogma Formation.

Yttrobetafite- $Y$ mineral is $U$ ions bearing as substitutional not as domain ions. The uranium (IV) ion has ionic radius nearly equal to that of calcium and REE of Y-group. This means that when crystals are formed, uranium can replace ions of these elements in the crystal lattices. 


\section{5- Cochromite:- $\left[\left(\mathrm{Co}, \mathrm{Ni}, \mathrm{Fe}^{2+}\right)(\mathrm{Cr}, \mathrm{Al})_{2} \mathrm{O}_{4}\right]$}

Cochromite detected within the siltstone and shale of Um Bogma Formation. X-ray powder-diffraction data (Fig. 6) showed that, $[d$ in $\AA(I)(h k l)$ are: $2.512,1.472$, 2.947 at $2 \theta$ angles $35.780^{\circ}, 62.590^{\circ}$ and $30.30^{\circ}$ respectively.

Cochromite is a member of multiple oxides belongs to spinel group occurring in sedimentary, igneous, and metamorphic rocks. It is known to incorporate an assortment of minor and trace elements. It is formed by replacing chromite cations for some nickel ions and considered as the inherited mineral from the source rock. Cochromite, in Bon Accord, South Africa, appears to have formed at $730^{\circ} \mathrm{C}$ and $<2 \mathrm{k}$ bar during thermal metamorphism that means the source of this mineral in the study area is related to the metamorphic province cropping out at Wadi El Seih out of the mapped area.

\section{6- Wakefieldite-(Y):-[YVO$]$}

The mineral has been investigated by X-ray powder Diffraction (Fig. 6) which reveals the data [d in $\AA$ ) as: $3.560 ; 1.824$; and 2.660 at $2 \theta$ angle $25.020^{\circ}, 49.610^{\circ}$, $35.060^{\circ}$ respectively. It was detected within the siltstone of Um Bogma Formation.

Wakefieldite is a member of rare-earth orthovanadates family $\left(\mathrm{RVO}_{4}\right),(\mathrm{R}=\mathrm{La}, \mathrm{Ce}, \mathrm{Nd}, \mathrm{Y}) \mathrm{VO}_{4}$, and the dominant rare earth yttrium group

\section{7- Bafertisite:- $\mathrm{Ba}\left(\mathrm{Fe}^{2+} ; \mathrm{Mn}^{2+}\right)_{2} \mathrm{TiOSi}_{2} \mathrm{O}_{7}(\mathrm{OH} ; \mathrm{F})_{2}$}

Bafertisite mineral is identified within shale of the lower member of Um Bogma Formation. It is recorded by the X-ray powder diffraction patterns (Fig. 6) corresponds to $d$ space values as $2.65,1.72$, and $2.11 \mathrm{~A}^{\circ}$, at $2 \theta$ angle $33.29^{\circ}, 54.24^{\circ}$ and $42.605^{\circ}$ respectively.

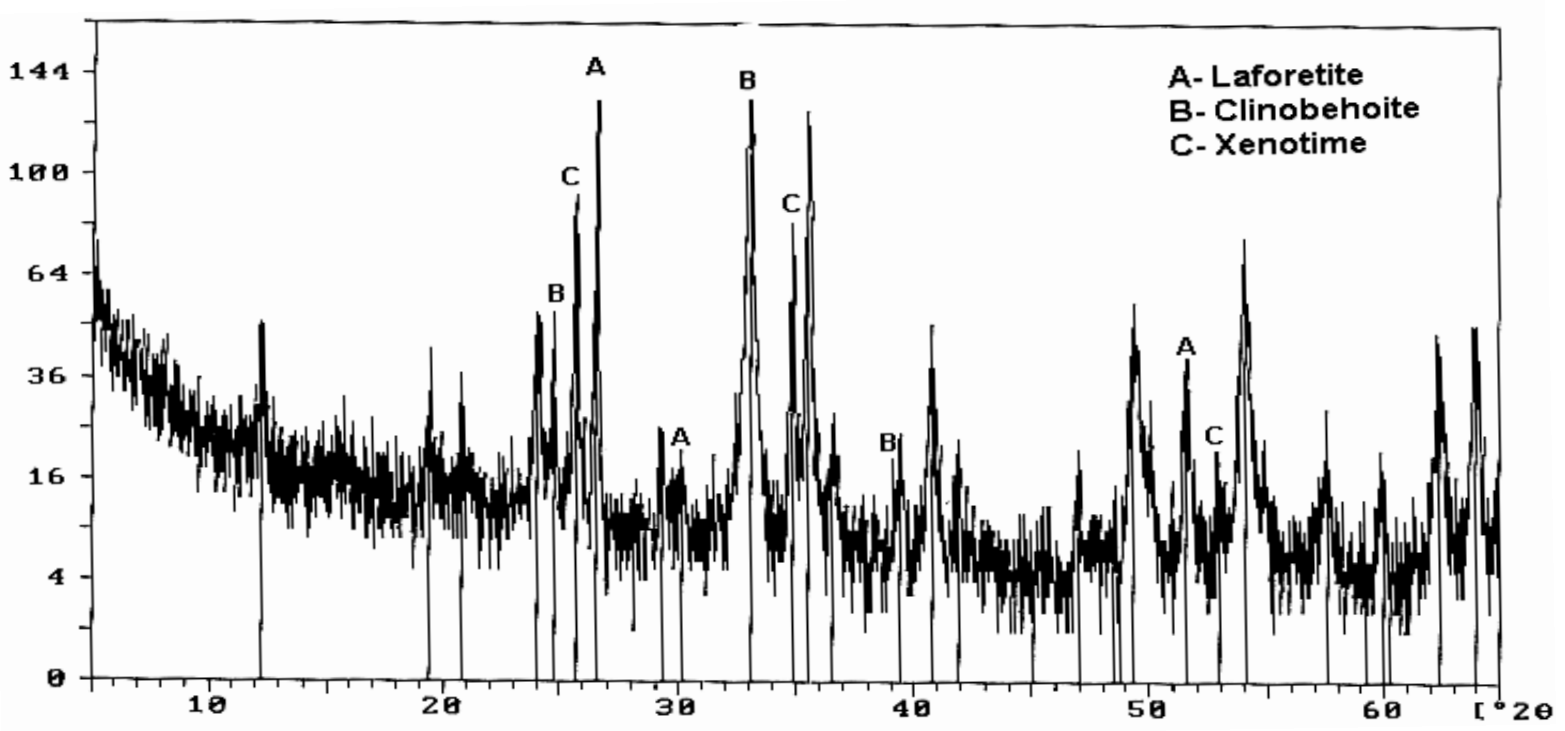

Fig. (3): X-ray diffraction patterns of laforetite, clinobehoite and xenotime, sheared monzo- and syenogranites, El Sheikh Soliman area.

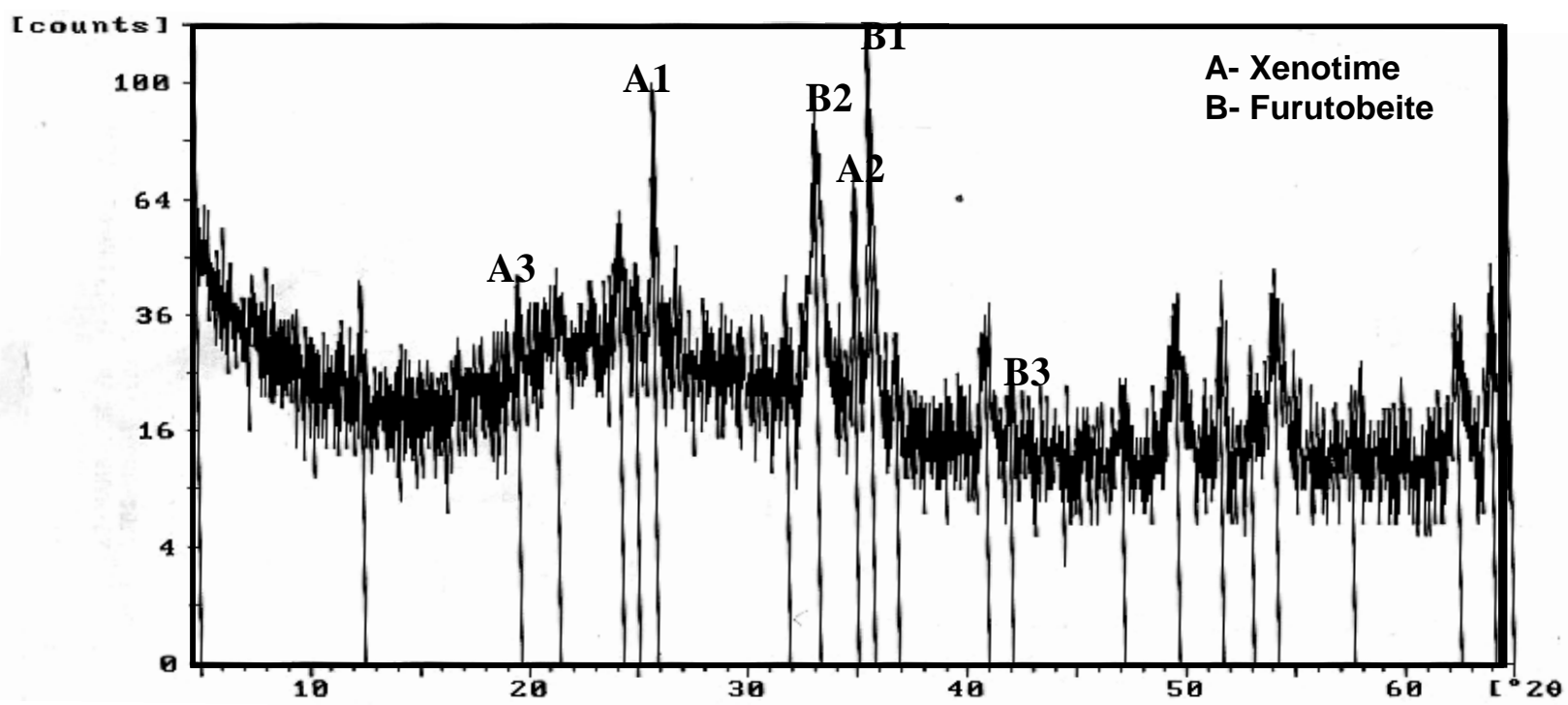

Fig. (4): X-ray diffraction patterns of xenotime-(Yb) and furutobeite, UM Bogma Formation, El Sheikh Soliman area. 


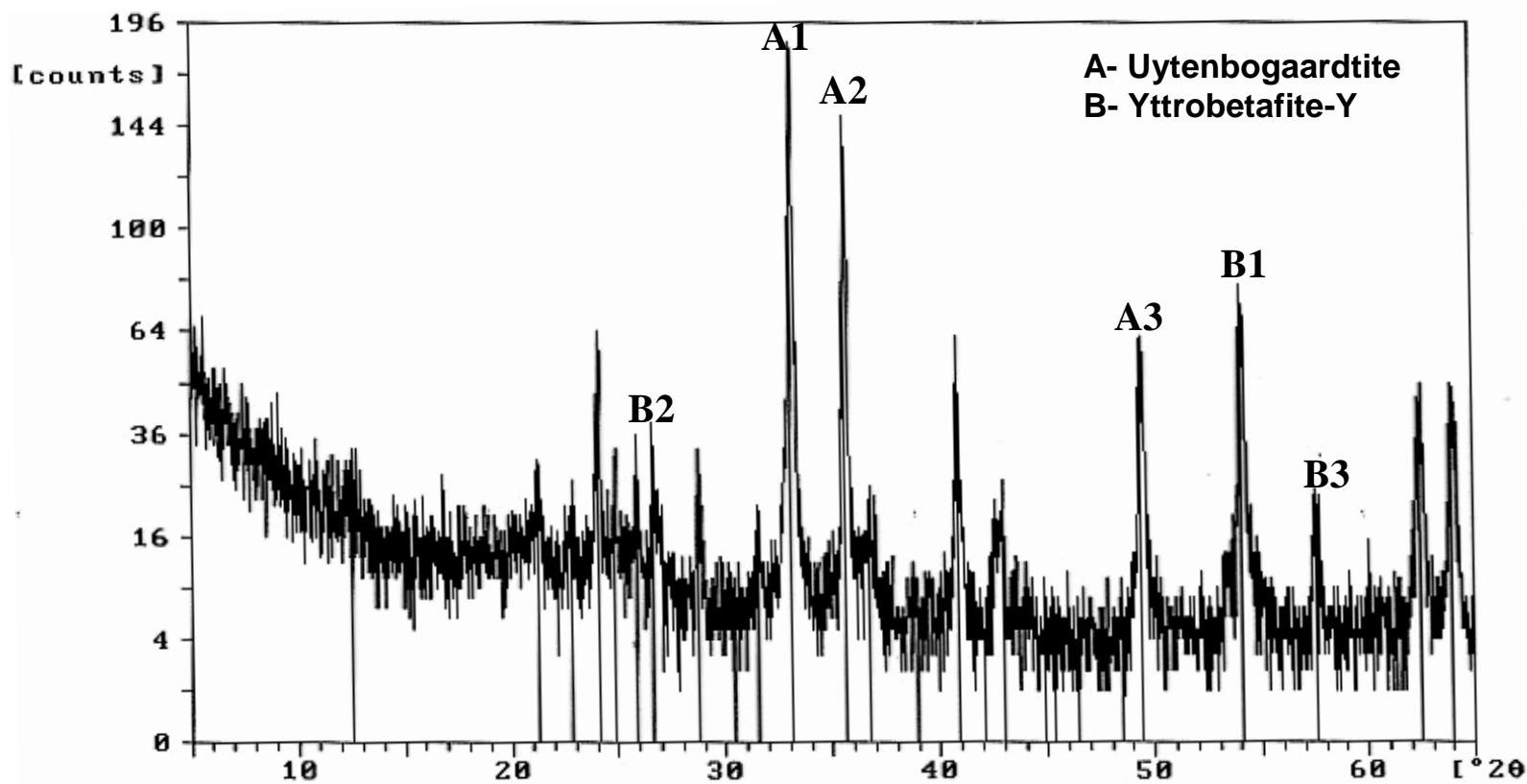

Fig. (5): X-ray diffraction patterns of Uytenbogaardtite and Yttrobetafite-Y minerals, Um Bogma Formation, El Sheikh Soliman area.

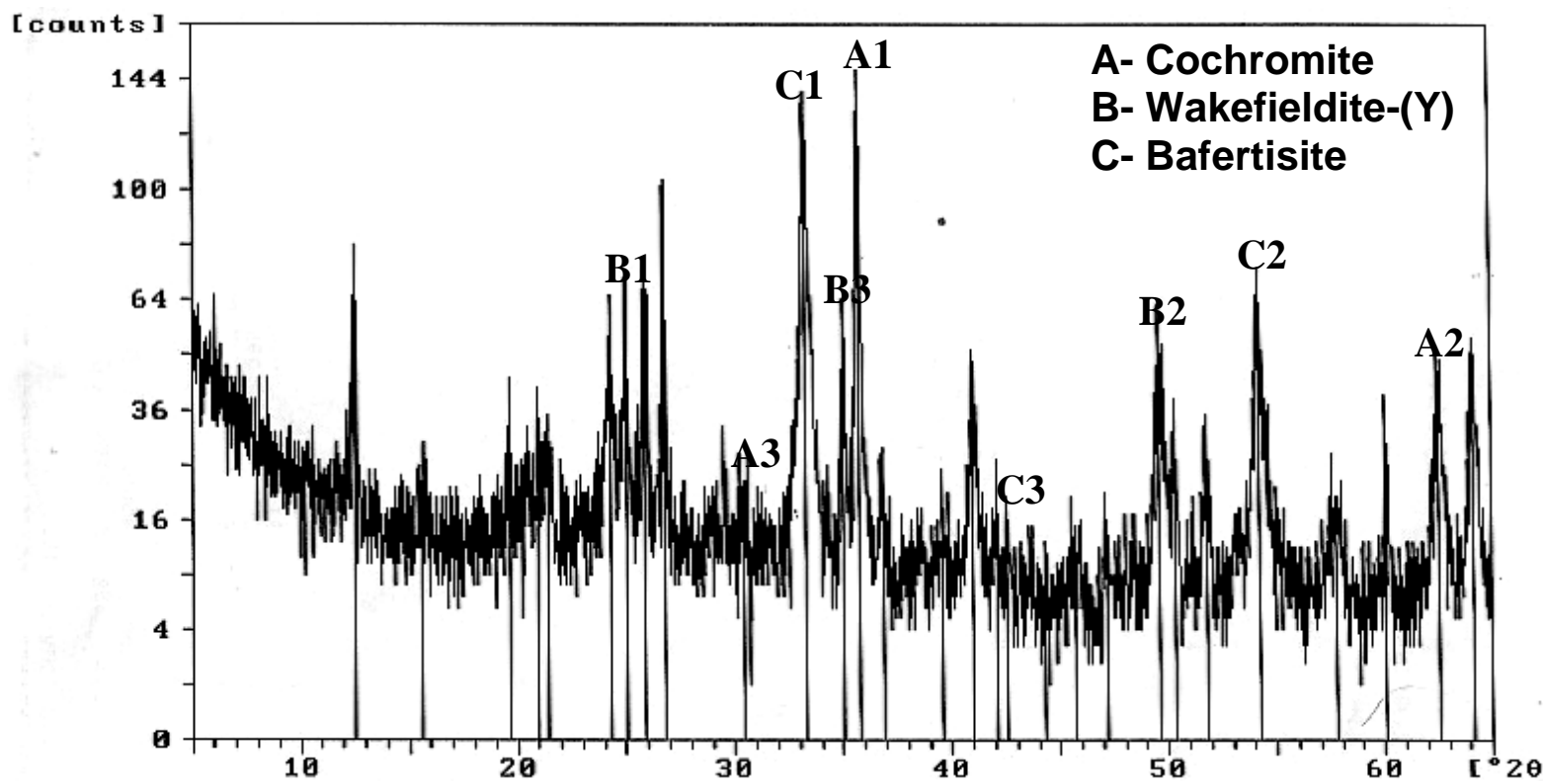

Fig. (6): X-ray diffraction patterns of Cochromite, Wakefieldite-Y and Bafertisite minerals, Um Bogma Formation, El Sheikh Soliman area.

\section{Conclusions}

In El Sheikh Soliman area, important minerals bearing $\mathrm{Ag}$ and $\mathrm{Au}$ such as uytenbogaardtite and furutobeite are first record in the Paleozoic lower member of Um Bogma Formation and laforetite (Ag-bearing) in altered monzo- and syenogranites shear zone.

The mineral assemblage of the mineralization in the lower member of Um Bogma Formation have important mineral assemblage include; xenotime, yttrobetafite-Y, cochromite, wakefieldite-(Y) and bafertisite. While that in altered monzo- and syenogranite shear zone includes; clinobehoite and xenotime.

Generally, the mineralized zones in El Sheikh Soliman area in part have features of hydrothermal origin in both altered monzo- and syenogranite shear zone and in lower member of Um Bogma Formation, while, in other part of the lower member of Um Bogma Formation they can be considered detrital paleoplacer deposit. 


\section{References}

1) Pichavant M. (1983). (Na, K) Exchange between alkali feldspars and aqueous solutions containing borate and fluoride anions, expremintal results at $\mathrm{P}=1 \mathrm{~K}$ bar [Z]. $3^{\text {rd }}$ NATO Adv. Stud. Inst., Feldspars and feldspathoids, Rennes. $102 \mathrm{p}$.

2) Cerny P. and Ercit T. C. (1985). Some recent advances in the mineralogy and geochemistry of $\mathrm{Nb}$ and $\mathrm{Ta}$ in rare-metal granitic pegmatites $[\mathrm{J}]$. Bull. Mineral., 10: 499-532.

3) Burt D. M. (1989). Compositional phase relations among rare earth elements. In Geochemistry and Mineralogy of Rare Earth Elements (eds. Lipin B.R. and McKay G.A.). J. Mineral. Soc. Amer., 21: 257307.

4) Schwartz M. O. (1990). Geochemical criteria for distinguishing magnetic and metasomatic albiteenrichment in granitoids: Examples from the Ta-Ti granite [Yichum (China)] and the Sn-W deposite Tikus (Indonesia) [J]. Mineral. Deposita, 27: 101108.

5) Abdalla H. M., Ishihara S., Matsueda H. and Abdel-Monem A. A. (1996). On the albiteenrichment granitoids at Um Ara area, Southeastern Desert, Egypt; I. Geochemical, ore potentiality and fluid inclusions studies [J]. Journal of Geochemical exploration, 57: 127-138.

6) El Afandy A. H., Abdalla H. A. and Ammar F. (2000). Geochemistry and radioactive potentiality of Um Naggat Apogranite, Central Eastern Desert, Egypt J. Res. Geol., 50: 39-51.

7) Sallam (2014). Radioactive shear zone at Gabal Ataiter El-Dahmi, southwestern Sinai, Egypt: Mineralogical and geochemical investigations. Scientific Society of Nuclear Materials Authority, 4.

8) Barron, T. (1907). The topography and geology of the peninsula of Sinai (Western portion), Egypt. Surv. Dept., Cairo, 241 p.

9) Soliman, M. S. and Abu El Fetouh M. A. (1969). Petrology of Carboniferous and sandstone in West Central Sinai, Egypt J. Geol. UAR, 13: 43-61.

10) Weissbrod, T. (1969). The Paleozoic outcrops in South Sinai and their correlation with those of southern Israel. In: The Paleozoic of Israel and adjacent countries. Bull. Geol. Surv., 2, 17, 32p.

11) Weissbrod, T. (1980). The Paleozoic of Israel and adjacent countries (Lithostratigraphic study). Report M.P. 600/81 Min. Res. Div. Geol. Sur. "Israel".

12) El Aassy, I. E., Botros, N. H., Abdel Razik, A., Sherif, H., Al Moafy, A., Aita, S. K., El Terb, R., Alshami, A. S. (1986). Report on the prospection and proving of some radioactive occurrences in west central Sinai, Egypt. Internal Repot. Nuclear Materials Authority (NMA), Cairo, Egypt.

13) El Aassy, I. E., Ahmed, F. Y., Alshami, A. S. and Shata, A. E. (1997). Contribution to uranium distribution in the Paleozoic section in Gabal Hemeyier, southwestern Sinai, Egypt. Egyptian
Journal of Geology, 41(2A): 205-218.

14) El Aassy, I. E., EL Moafy, A. A., Hilmy, M. E. and Sallam, O. R. (2003). The control of uranium distribution in the Paleozoic sedimentary section of Um Bogma area, southwestern Sinai, Egypt. Egyptian journal of geology, 47(2): 1325-1339.

15) Amer, T. E. (1993). Physical and chemical studies on the uranium copper mineralization of uraniferous Paleozoic sediment, west central Sinai, Egypt. M.Sc. Thesis, Faculty of Science, Cairo University, Egypt, $163 \mathrm{p}$.

16) Mahdy, M. A., El Aassy, I. E., El Agami, N. L., Hegab, O. A. and Shata, A. E. (1998). Geochemical behavior of uranium in ground water and stream sediments of southwestern Sinai, Egypt, $4^{\text {th }}$ Arab conference on the peaceful uses of Atomic Energy Tunis: 69-92.

17) El Agami, N. L., Ibrahim, E. H. and Odah, H. H. (1999). Palieomagnetic and geologic inferences and probable origin of $\mathrm{Mn}-\mathrm{Fe}$ ore of Um Bogma, southwestern Sinai, Egypt. Sedimentology of Egypt, 7: 167-183.

18) El Agami, N. L. (1996). Geology and radioactivity studies on the Paleozoic rock units in the Sinai Peninsula, Egypt. Ph.D. Thesis, Faculty of Science, Mansoura University, Egypt, 302 p.

19) Aita, S. K. (1996). Geological, mineralogical and geochemical studies on some radioactive anomalies of the Paleozoic sediments of Um Bogma area, west central Sinai, Egypt. M.Sc. Thesis, Faculty of Science, Cairo University.

20) Ghonaim, A. Kh., El Hazak, N. M. T., Ahmed, F. Y. and El Fattah, N. A. (2002). Extraction of valuable metals of gibbsite ore material from Sinai, Egypt. Bull. Fac. Sci. Zagazig Univ.: 29-39.

21) Ghonaim, A. Kh., El Hazak, N. M. T., Ahmed, F. Y. and El Fattah, N. A. (2004). Acid leaching and recovery of the metal values of the gibbsite bearing Um Bogma Formation west central Sinai, Egypt. Al Azhar Bulletin of Science, 15(1): 29-42.

22) El Aassy, I. E., El Metwally, A. A., Sherif, H. M., Abu Bakr, M. A. and Bishr, A. H. (2004). Petrography, geochemistry and mineralogy of Wadi Um Hamd younger granites, southwestern Sinai, Egypt. $6^{\text {th }}$ Intern. Conf. On Geochemistry, Alex. Univ., Egypt: 543-575.

23) El Akeed, I. A., Sallam O. R., Alshami A. S. and Zaeimah M. A. (2014). Polymetallic mineralization controlled by structure and lithologic factors, Wadi Sedri environs, southwestern Sinai, Egypt. Geological Society of Egypt, 58.

24) El-Aassay, I.E. Botros, N.H. Ibrahim, M. E. Hammd, M.S. and Hassan, M.A. (1993). A new beryl occurrence in Sinai, Egypt. Egyptian mineralogist, 5: 1-10.

25) Abdalla, H. M. and Mohamed, F. H. (1999). Mineralogical and geochemical investigation of emerald and beryl mineralization, Pan-African Belt 
of Egypt: genetic and exploration aspects. J. African Earth Sciences, 28(3): 581-598.

26) Sherif, H. M., Abd El-Aaty, M. A., Lasheen, T. A. and El-Shamy, A. S. (2005). New beryl occurrence of Wadi Sedri, southwestern Sinai, Egypt. The fourth international conference on the geology of Africa, (NOV. 2005) Assiut-Egypt, 2: 471-477.
27) El-Kammar, A. M., El Aassy, I. M. and Abram, F. B. (1997). Rare earth elements and crystal chemistry of Xenotime bearing sediments of Um Bogma area, south western Sinai, Egypt. Chemie Der Erde, 57(1): 91-101.

28) Cook, J. N. and Chryssoulf, L. S. (1990). Concentrations of "invisible gold" in the common sulfides. Canadian Mineralogist, 28: 1-16. 